\section{Zentrale Apnoe}

Helga Peter

Marburg, Deutschland

\section{Englischer Begriff}

central apnea

\section{Definition}

Periodisch auftretendes Sistieren des Luftflusses an Mund und Nase bei fehlender „Atmungsanstrengung“ (Effort).

Siehe auch

- „Schlafbezogene Atmungsstörungen“

- „Atmungsmessung“ 